SLAC - TN $-87-1$

February 1987

(TN)

\section{USING THE SLAC VHF AND UHF RADIO SYSTEMS}

$$
\text { SLAC-TN--87-1 }
$$

\section{W. STRUVEN}

DE87 008135

\section{Stanjord Linear Accelerator Center}

Stanford Univeraity, Stanjord, CaliJornia, 94905

\section{ABSTRACT}

This note has buen written to aescribe the use of the SLAC VIIF and UHF Radio Systems and the Tunnel Antenna Syatems as they are presently configured. The original radio system was built in 1906 and has grown in scope over the years. The Tunnel Antenra Systems were developed for, and first installed in, the PEP ring, and later added to other tunnels and redesigned to cover the UHF range, as well as VHF. The UHF radio system was designed and built for SLC use, and was first used in the SLC Arcs.

The three radio systerns will be described and the capabilities of each system will be defined.

\footnotetext{
- Work supported by the Departmenn of Energy, contract DE - AC03 - 76SFo0515.
}

\section{Introduction}

Radio communication has been a necessily at SLAC since the accelerator was built. At first, radio was ured to communicate between the control rooms and people around the SLAC site. Radio communicalions were very soon requirzd between the control rooms and ine BSY and later to the $A, B$ and $C$ beam lines. That problem was solved using "Passive entennae", which consisted of two antennae, one above ground, and one below ground connected by couxial cablec. This was an adequate solution for the BSY, but did not work well in the PEP tunnels. That led to the development of the "Turnel Antenna System", SLAC-PUB-2567 - July, 1980.

\section{VHF Radio Systems}

The purpose of these systems was to provide radio zommunications between control roorm and people around the SLAC site (two-wny voice system) and a radio paging ayatem for on-site and off-site one-way voice paging. Four VHF frequencies are availabie; operations frequency $164.35 \mathrm{MHz}$, Security/Transportation 167.875 MHz, Radio Paging 167.9 MHz and Experimenters 167.925 MHz. Re mote base units have been provided on the operationa frequency and on the security frequency. $A$ remote base unit permits speration of the high power fixed transmittera and receivers from MCC and other aelected locations around SLAC (See Figure 1.). Radio paging is provided through the SLAC phone ayrtem.

\section{Tunnel Anterna Syaterms}

The Tunnel Antenna Syatem was developed at SLAC to extend radio communications to underground tunnels. The first tunnel that had such a aystem was the PEP Ring- The passive antenna systems used in the BSY were not adequate, so two active "leaky fecder" systems were installed around the PEP Ring; one to carry signals isto the ring, and one to carry gignals out of the ring. This provided the means to communicate from one handuteld portable to another in the PEP Ring, as well as from a remote base to/from a portable radio in the PEP Ring. (Sce Figure 2.) All four VHF frequencies are carried by the Tunnel Antenna 
System simultaneously. The Tunnel Antenna Syatem was recently modified to carry UHF signale aleo. This teature will be described later.

\section{Capabilities of the VHF Radio Syatem (See Figures 1 and 2)}

1. Communicalions between remote bases and portables above ground or in the PEP tunnel, SLC Arco and FF or the Accelerator Housing are pussible.

2. Communications are not possible from the tunnels to a portable above ground (around the site).

3. Portable to Portable communications in the North PEP Tunnel, or the South PEP Tunnel, or the North SICC Arc or the South Arc or the Accelerator Housing, are possible.

4. Portable to portable communicatlons are nat possible from N PEP to $S$ PEP, or from NARC to SARC (SLC), or from any of the tunnels to the Accelerator Houging on VHF.

5. Paging can be heard in any of the above tunneln.

\section{UHF Radio Sy:tem}

The purpose of the UHF Radio System is to provide above-ground to belowground radio communications, as well as site communications. Six frequenciea wo available an follows: Ch1 and $\mathrm{Ch} 2$ (on the portable radios) hove repeater stations and $\mathrm{Ch} 3,4,5, \mathrm{~B}$ do not hove repeaters (See Figure 3). The repeater stations, located at Bldg. 136, rebroadcast a signal from a portable so that the pirtable can communicate with another portable above ground, as well as below ground (in the NARC and SARC tunnela and the Accelerator llousing). Ch1 and $\mathrm{Ch2}$ have beparate repeater syelems, so separate conversations can be carried on each channel. In addition, Ch1 hr i a tslephone interconnect. The telephone isterconnect permita you to dial into the SLAC phone syatem using a UHF portable. To axtivate the telephone interconnect from the SLAC phone system to purtables, call Ext. 3663. Figure 4 showa the connection of the UIIF radio system with the Tunnel Radio System. Figure 5 is the UnF portable operating instructions.

\section{Gapabilities of the UIIF Radio System}

1. Communication should be possible between portables above ground and/or below ground in the SARC and NARC tunnels and Final Focus pit, as well as the Accelerator Housing.

2. The PEP Tunnel enterina aystem will not carry UHF signals, only VHF signals.

3. Portable to portable communications should be possible almost anywhere on the site using the $\mathrm{Ch} 1$ or $\mathrm{Ch} 2$ repeaters, and in all of the above tunnels, except PEP.

4. Porkable to portable communications using $\mathrm{Ch} 3,4,5$ or 6 should be possible if there is a line of sight between two portablea. These channela do not have repenters.

5. When MCC becomes operational on UHF, Ch2 will be the culling requency to reach MCC. They will have capebility of operating on $\mathrm{Ch} 1,3,4,5$ and 6, also, bus will llaten for calls and communicate on $\mathrm{Ch2}$.

If, after you have read this nole, and all elae fails, call Warren Struven on x3533.

WS:kf 

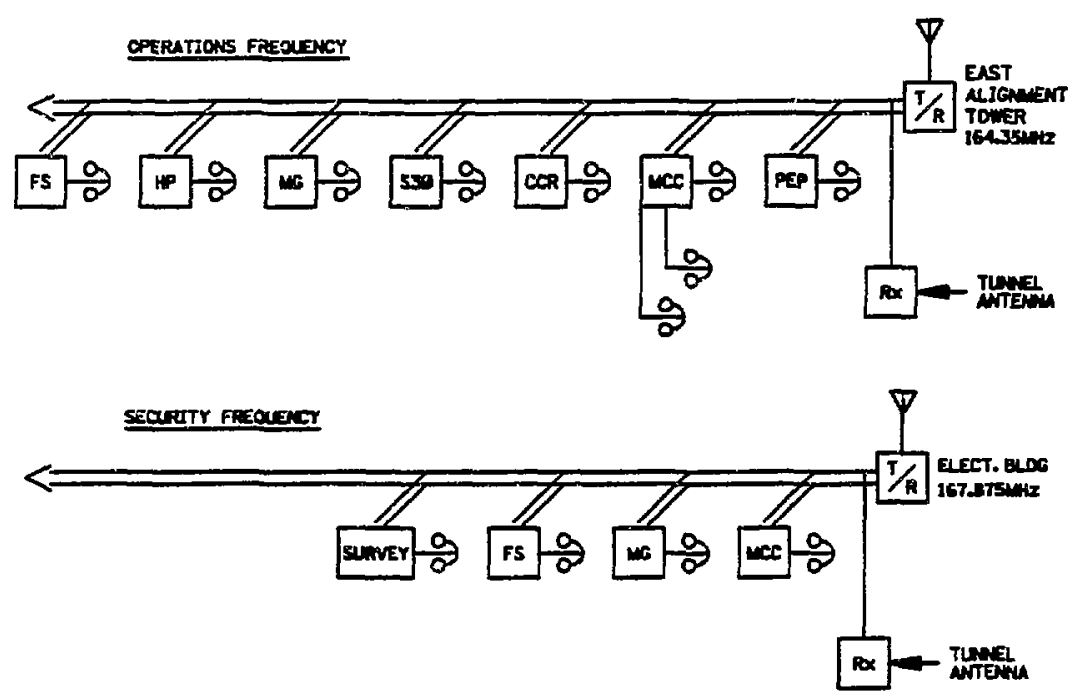

Fig. 1
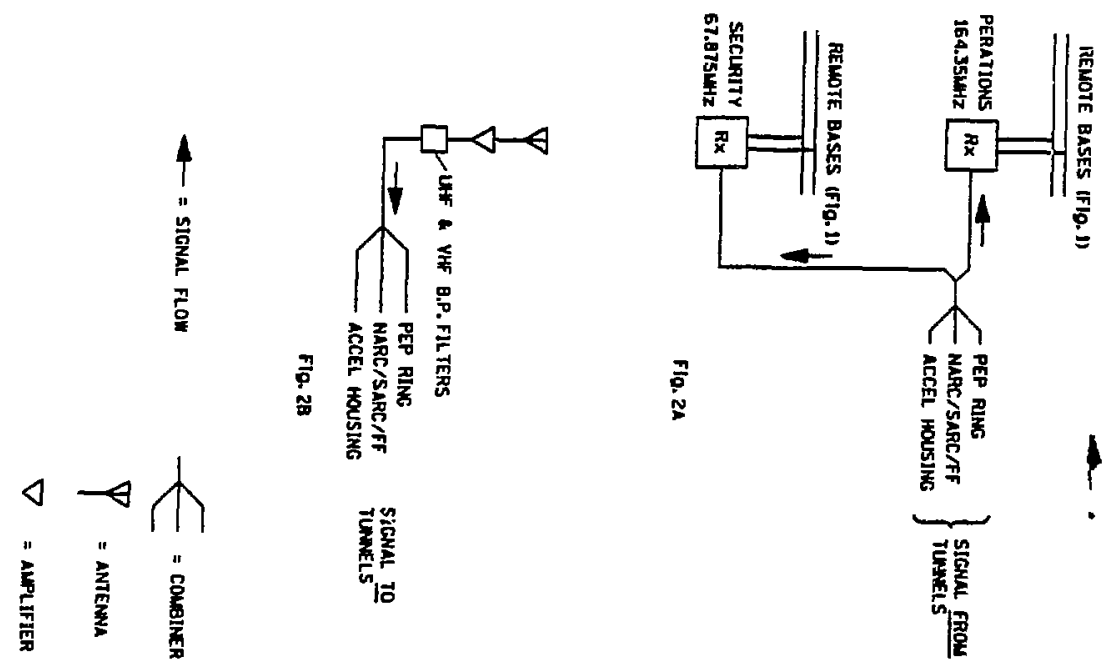


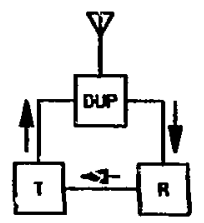

CH 2

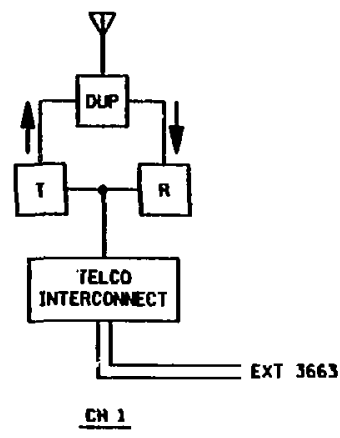

$r$. TRANSMITTER

DUP = DUPLEXER

R = RECEIVER

$\boldsymbol{\nabla}$ - anterau

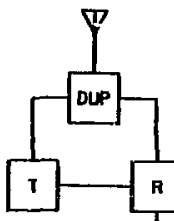

R

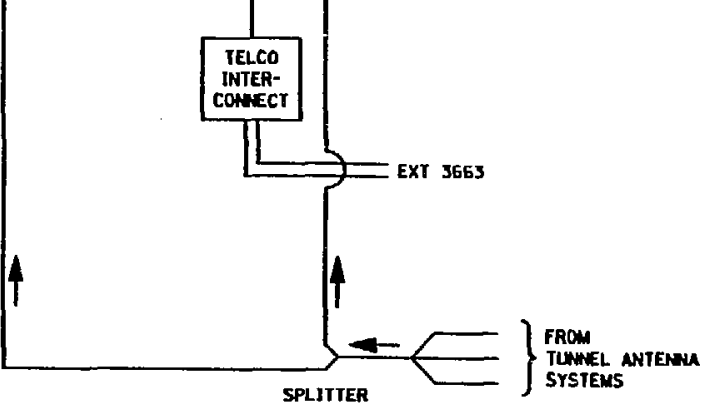

COWBJER

(FIg. 2A)

Fip. 3 


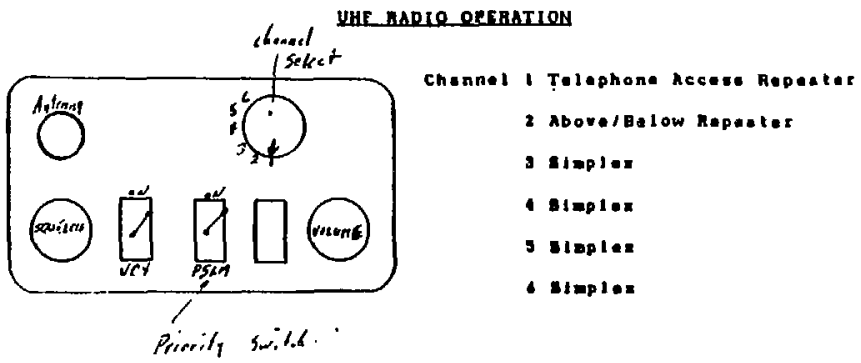

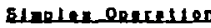

Channels 3 thru can be ued above ground or tn the Tunnel (1ater) tor Handy Talke (H.T.) to H.T. diret comentcationa."

\section{AbprelBebow Hepenter.}

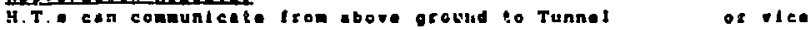
verwa, Chennel 2 . It both HT' aze not on chernel, aet up comul nicelions by telephone or pepera. A perif-iline cail cen reault it Dere then two H.T." are on channei $z$.

To call a sac telephone trod H.T., gelect channel 1 It telephone interconnect is buey you will heer volce converealione is not, prose Trenent button end on T.T. Fad together end toleat you hould hear dial tone. Touch tone gour blac nua-

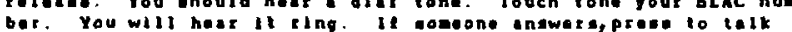

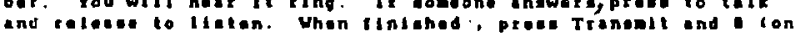

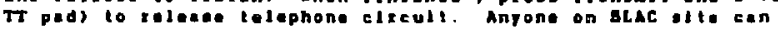
call H.T. by dieling tha sie medto number ass. The HT guet have channel 1 ablected or have the Prtority owlich on when any other chennel le enlected. You will heer beeplng lone on channe1 1. The HT eperator auel ewltch to CH1 and press Trangelt and

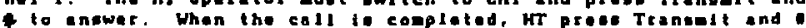

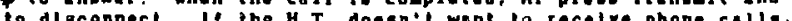

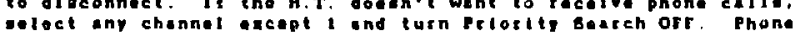
calle can be placed ot recalved trob above ground or in the tun$n \in 1$,

When the telophone Interconnect is not requtred, Channel 1 can be used as " normal repenter" t.e., fuat ltke channel $z$.

$$
\text { f.g } 5
$$




\section{DISCLAIMER}

This repart was prepared as an account of work sponsored by an agency of the United States Government. Neither the United States Government nor any agency thereof, nor any of their emplnyees, makes any warranty, express or implied, or assumes any legal liability or responsjbility for the accuracy, completeness, or usefuhness of any information, apparatus, product, or process disclosed, or represents that its use would not infringe privately owned rigbts. Reference herein to any specific commercial produch, process, or service by trade name, trademark, manufacturer, or otherwise does not necessarily constitute or imply its endorsement, recommendation, or favoring by the United States Govemment or any agency thereof. The views and opinions of authors expressed berein do not necussarily state or reflect those of the United States Government or any agency thereot. 